Tjalling C. Koopmans Research Institute

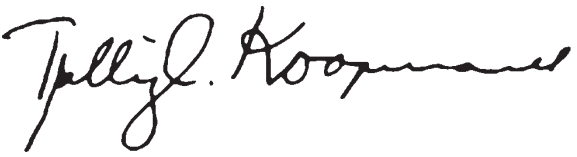

Discussion Paper Series nr: 07-22

\title{
Testing the Linkages between Trade and Productivity Growth
}

Claire Economidou, Antu Panini Murshid

(Forthcoming at the Review of Development Economics) 


\section{Tjalling C. Koopmans Research Institute Utrecht School of Economics \\ Utrecht University}

Janskerkhof 12

3512 BL Utrecht

The Netherlands

telephone $\quad+31302539800$

fax $\quad+31302537373$

website www.koopmansinstitute.uu.nl

The Tjalling C. Koopmans Institute is the research institute and research school of Utrecht School of Economics.

It was founded in 2003, and named after Professor Tjalling C. Koopmans, Dutch-born Nobel Prize laureate in economics of 1975.

In the discussion papers series the Koopmans Institute publishes results of ongoing research for early dissemination of research results, and to enhance discussion with colleagues.

Please send any comments and suggestions on the Koopmans institute, or this series to s.mook@econ.uu.nl

ontwerp voorblad: WRIK Utrecht

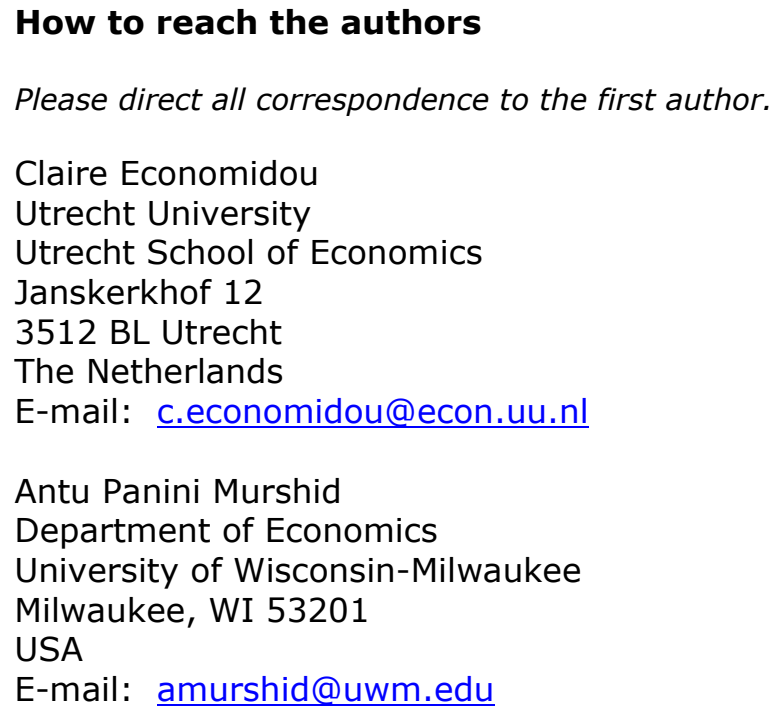

Please direct all correspondence to the first author.

Claire Economidou

Utrecht University

Utrecht School of Economics

Janskerkhof 12

3512 BL Utrecht

The Netherlands

E-mail: c.economidou@econ.uu.nl

Antu Panini Murshid

Department of Economics

University of Wisconsin-Milwaukee

Milwaukee, WI 53201

USA

E-mail: amurshid@uwm.edu 
Utrecht School of Economics

Tjalling C. Koopmans Research Institute

Discussion Paper Series 07-22

\title{
Testing the Linkages between Trade and Productivity Growth
}

\author{
Claire Economidou ${ }^{a}$ \\ Antu Panini Murshid \\ aUtrecht School of Economics \\ Utrecht University \\ ${ }^{b}$ Department of Economics \\ University of Wisconsin-Milwaukee
}

March 2007

\begin{abstract}
We examine the effect of trade on productivity growth using data from nine manufacturing industries across twelve OECD countries over the period 1978-1997. Since causality between productivity growth and trade share runs both ways, geographical characteristics of countries are used to instrument for average bilateral trade volumes over the 20-year period. In addition, to exploit the time-series nature of the data, we construct a panel data set and employ dynamic panel data techniques. After controlling for industry-specific heterogeneity, our results indicate that increased exposure to trade, in particular higher import volumes, exerts a positive influence on industries' productivity growth. However, the effect is rather small.
\end{abstract}

Keywords: Productivity Growth, Trade, Gravity Model of Trade, Manufacturing Industries

JEL classification: F14, F43, 047

\section{Acknowledgements}

We wish to thank loannis Filippidis, Clemens Kool, and Harry Garretsen for their valuable comments. Any remaining error is ours. 


\section{Introduction}

Does trade exert a positive influence on economic performance? This is a question of longstanding interest and a question that has become increasingly relevant as lower transportation costs and shifts toward freer trade have dramatically increased bilateral trade volumes. For many, the case for trade liberalization is clear (Bhagwati, 1998) while others are more skeptical (Rodriguez and Rodrik, 1999). Despite numerous studies finding evidence of a positive link between trade and growth, the controversy has been far from settled. There are at least two reasons for this.

First, it has been difficult to establish a theoretical link between trade and growth. The issues of economic growth and trade have typically been treated independently of each other; dynamic models of closed-economies are the standard benchmark in the orthodox growth literature, while static open-economy models are the norm in the theoretical literature on trade. With the advent of new growth theory some studies have considered the implications of trade for growth (Grossman and Helpman, 1991; Rivera-Batiz and Romer, 1991). However, even within these contexts the role of trade is limited; under the assumption that the cost of adopting existing technologies is less costly than innovating, attention centers on the role of trade as a vehicle for transmitting knowledge.

Second, the empirical literature on trade and economic performance has been plagued by serious data problems. Unsatisfactory measures of openness to trade question the validity of observed links between trade policy and economic performance while direct attempts to establish the consequences of trade are unable to offer persuasive evidence in the face of bidirectional causality (Rodriguez and Rodrik, 1999). 
In this paper we re-examine empirically the impact of trade on economic performance. However, our focus is on the consequences of trade for productivity growth rather than growth per se. The central contribution of the paper is its attempt to correct for biases on account of simultaneity between trade and productivity growth.

Existing empirical studies, which have focused on trade and productivity growth, have attempted to identify trade's effect by including trade directly in the right hand side of otherwise standard growth regressions. These findings are not necessarily persuasive since correlations between trade and productivity growth are not evidence of the effect of trade on the latter.

Specifically, studies that have examined the causal effect of trade on growth at an aggregate level, have typically found a positive link between the two (Levine and Renelt, 1992; Harrison, 1996; Edwards, 1998). However, when the focus has centered on the effect of trade on sectoral productivity performance across OECD countries, no consensus seems to have emerged. For instance, some studies support a strong impact of trade, especially of imports, on productivity growth (MacDonald, 1994; Keller, 1999; Cameron et al., 2005) while other studies find little (Griffith et al., 2004) or no impact of trade at all (Cheung and Garcia Pascual, 2004).

Our paper is related to the strand of literature that explores, among other factors, the role of trade on productivity growth in the manufacturing sector across OECD countries. The value-added of our approach is that it is explicitly designed to overcome some of the problems - not adequately addressed in previous studies - associated specifically with measuring the impact of trade. We do not try to offer any nuanced conclusions as to the role of trade, but simply to establish a link between the volume of trade and productivity growth, 
if in fact such a link exists. As such, our approach tries to complement these important earlier studies cited above.

Our evidence is based on data from nine two-digit manufacturing industries in twelve OECD countries from 1978 to 1997 . We employ two econometric procedures to assess the relationship between trade and productivity growth and to deal with possible biases arising on accounting of simultaneity.

First, we use a pure cross-sectional, instrumental-variables estimator. The gravity model of trade motivates our choice for instrumental variables. We use the geographical characteristics of countries, namely size and proximity to instrument for bilateral trading volumes. ${ }^{1}$ To assess the impact of this exogenous component of trade on productivity growth, we use a sample with data averaged over the period under investigation.

Second, to exploit the time-series nature of the data, we construct a panel data set and employ dynamic panel data techniques proposed by Arellano and Bond (1991) in order to extract consistent and efficient estimates of the impact of trade on productivity growth. This procedure controls for possible endogeneity of the regressors and for industry specific effects in a dynamic, lagged-dependent variable model.

Our cross-sectional evidence suggests that international trade has a positive and statistically significant impact on productivity growth. This relationship also seems to hold within industries over time. However, the evidence from the panel estimates points to import volumes, as opposed to exports, as the major factor in determining productivity increases.

The remainder of the paper proceeds as follows. Section 2 describes the methodology and data. Section 3 provides estimates for the effect of trade on productivity growth and discusses the results. Section 4 concludes. 


\section{Methodology}

\section{Measuring Productivity Growth}

The starting point for our analysis involves calculating a measure of total factor productivity (TFP) growth. Suitable measures of output and factor inputs are thus required, as well as, measures of output elasticities of inputs, which are assumed to be equal to the income shares of capital and labor.

Following relevant studies (Caves et al., 1982; Scarpetta and Tressel, 2002; Griffith et al., 2004), the (productivity) index used as a measure TFP level is:

$$
T F P_{i j t}=\ln \left(\frac{Y_{i j t}}{\bar{Y}_{. j t}}\right)-\sigma_{i j t} \ln \left(\frac{L_{i j t}}{\bar{L}_{. j t}}\right)-\left(1-\sigma_{i j t}\right) \ln \left(\frac{K_{i j t}}{\bar{K}_{. j t}}\right)
$$

where $Y_{i j t}$ is real output (value-added) in country $i$, industry $j$ at time $t, L_{i j t}$ and $K_{i j t}$ are, respectively, inputs of labor and physical capital, while a bar above the variable denotes a geometric mean in industry $j$ at time $t$. The variable $\sigma_{i j t}=\frac{1}{2}\left(a_{i j t}+\bar{a}_{. j t}\right)$ is the average of the labor share in value-added in country $i$ and industry $j, a_{i j t}$, and the geometric mean of the labor share in industry $j, \bar{a}_{. j t}$.

The growth of TFP is then measured as a superlative index number derived from a constant-returns-to-scale translog production function:

$$
\Delta T F P_{i j t}=\Delta Y_{i j t}-\frac{1}{2}\left(a_{i j t}+a_{i j t-1}\right) \Delta L_{i j t}-\left[1-\frac{1}{2}\left(a_{i j t}+a_{i j t-1}\right) \Delta K_{i j t}\right]
$$

\section{Model and Estimation Approach}

Productivity growth, in any industry, is spurred by new technological innovations occurring at the frontier country for a given industry, and through the diffusion of existing technologies (Bernard and Jones, 1996; Scarpetta and Tressel, 2002; Griffith et al., 2004; Cameron et al., 
2005). In the context of total factor productivity, this can be modeled as an auto-regressive distributed lag $A D L(1,1)$ process in which the level of TFP is co-integrated with the level of TFP of the technological frontier country, $F$ (defined as the country with the highest level of TFP in a given industry). Formally,

$$
\operatorname{lnTFP} P_{i j t}=\alpha_{l} \operatorname{lnTFP} P_{i j t-1}+\alpha_{2} \ln T F P_{F j t}+\alpha_{3} \ln T F P_{F j-l}+u_{i j t}
$$

where $u_{i j t}$ captures the observable and unobservable factors influencing the level of TFP. Under the assumption of long-run homogeneity ( $\left.1-\alpha_{1}=\alpha_{2}+\alpha_{3}\right)$, equation (3) yields,

$$
\Delta \operatorname{lnTFP} P_{i j t}=\alpha_{2} \Delta \operatorname{lnTFP} P_{F j t}-\left(1-\alpha_{1}\right) G A P_{i j t}+u_{i j t}
$$

where $\triangle T F P_{i j t}$ is the growth rate of total factor productivity in country $i$, industry $j$ at time $t$; $\triangle T F P_{F j t}$ is the growth rate of total factor productivity in the frontier country $F$, industry $j$ at time $t$; GAP $i j t$ is the technological gap between country $i$ and the frontier country, $F$, for a given industry $j$ at time $t\left(G A P_{i j t}=T F P_{i j t}-T F P_{F j t}\right)$.

Equation (4) is an equilibrium correction model (ECM) representation of the long-run cointegrating relationship (3). The residual term in equation (4) can be modeled as:

$$
u_{i j t}=\beta_{k} T_{i j t-1}+\beta_{k+1} X_{i j t-1}+\varepsilon_{i j t}
$$

where $T_{i j t}$ is the trade share, $X_{i j t}$ is a set of other control variables affecting TFP and $\varepsilon_{i j t}$ is an iid shock.

At a steady-state equilibrium, the independent variables are constant over time $\left(u_{i j t}=u_{i j}\right)$ and the total factor productivity in sector $j$ grows at the same constant rate in all countries: $\triangle \operatorname{lnTFP} P_{i j t}=\triangle \operatorname{lnTFP} P_{F j}$.

Setting in equation (4) $\alpha_{2}=\beta_{1}$ and $\alpha_{1}-1=\beta_{2}$ and combining equations (4) and (5), the empirical specification under estimation is: 


$$
\Delta T F P_{i j t}=\beta_{1} \Delta T F P_{F j t}+\beta_{2} G A P_{i j t}+\beta_{3} T_{i j t}+\beta_{4} X_{i j t}+\varepsilon_{i j t}
$$

In presence of technology transfer from the frontier country, $F$, in industry $j$, the estimated coefficient on $\triangle T F P_{F j t}$ is expected to be positive and statistically significant. A negative and statistically significant estimated coefficient on $G A P_{i j t}$ will indicate convergence among industries across countries.

Trade share $\left(T_{i j t}\right)$ either in the form of exports or imports, is a proxy of growthenhancing interactions such as specialization, economies of scale, technology spillovers. As for the latter, it has been argued that both exports and imports are vehicles of knowledge dissemination and, therefore, could raise industry's productivity. ${ }^{2}$ In particular, exports facilitate the exchange of ideas while imports of quality foreign goods serve as a means of acquiring foreign technology via reverse-engineering. As industries successfully imitate quality imported goods they gain more insight as to how these goods are engineered, and can improve upon. Therefore, the estimated coefficient on trade share (export share, import share) is expected to be positive.

In addition to trade, we consider a number of control variables $\left(X_{i j t}\right)$, namely, research and development (R\&D), a proxy for market structure (price-cost margin), sunk costs, and government spending that can affect total factor productivity.

According to Schumpeterian models of growth and new growth theory (Romer, 1990; Grossman and Helpman, 1991; Aghion and Howitt, 1998), research and development stimulates innovation and facilitates imitation of new technologies and, therefore, is considered to be an important factor in generating productivity growth.

The structure of the market that an industry operates can also influence the productivity growth of the industry. Much of the literature on new growth theory implies a 
negative relationship between increased competition and productivity growth. However, as Aghion et al. (1997) have argued, lower profits place greater pressures on managers to adopt new technologies in order firms to survive; thus, increased competition could also positively impact on productivity. To account for the effect of the structure of the market in our analysis, we follow the empirical literature (Domowitz et al., 1986; Campa and Goldberg, 1995; Cheung et al., 2001; Garcia Pascual and Cheung, 2004) and construct a proxy for market structure, price-cost margin $(P C M)$, which approximates the profitability of an industry. The $P C M$ for industry $j$ in country $i$ at time $t$ is defined as, $P C M=\frac{V_{i j t}-M_{i j t}-L C_{i j t}}{V A_{i j t}+M_{i j t}}=\frac{V A_{i j t}-L C_{i j t}}{V_{i j t}}$, where $V$ is the value of the total production (sales), $M$ is the cost of the materials, $L C$ is the labor compensation and $V A(=V-M)$ is the value-added. Consequently, lower values of $P C M$ correspond to increased competitiveness.

We also include sunk costs as a control variable. The presence of high sunk costs deters firms from entering the market. According to Dixit (1989), an over-investment strategy deters potential entrants and, thus, limits the extent of foreign direct investment, which is a channel for technology diffusion. Physical investment normalized by production in an industry is used as a proxy for sunk costs. Therefore, a negative relation is expected between sunk costs and productivity growth.

Lastly, the role of government spending is also considered ${ }^{3}$. A number of studies have examined empirically the influence of spending on total factor productivity growth (Aschauer, 1989; Cheung and Garcia Pascual, 2002) offering, however, mixed results. The aggregate measure of spending, often used in the past literature, can mask the impact of various components of spending on productivity growth ${ }^{4}$. Therefore, we account for the role 
of government spending on total factor productivity growth by considering the spending on productive activities (education, transport and communication).

We estimate two sets of regressions using both cross-sectional and panel data. While there are some differences in specification across the two approaches, in each case, the equation under estimation is $(6)^{5}$

We use two econometric procedures to assess the relationship between trade and productivity growth and to deal with possible biases arising on accounting of simultaneity. First, we employ a pure cross-sectional instrumental-variables estimator. As in Frankel and Romer (1999), trade share is instrumented by using geographic characteristics of the countries involved in trade. The fitted trade values derived from the gravity model of trade are aggregated across countries to create an instrument for the actual trade share. The dependent variable, which in this case is the average rate of productivity growth over the 20year period from 1978 to 1997 , is then regressed against the average volume of (instrumented) trade over the same period, along with a number of other explanatory variables.

Second, we construct a panel dataset with data averaged over four five-year periods between 1978 and 1997. We then use the GMM estimator proposed by Arellano and Bond (1991) to extract consistent and efficient estimates of the impact of trade on productivity growth. The panel estimator conveys a number of advantages over the cross-sectional estimator. First, it exploits the time-series variation in the data, accounts for unobserved industry-specific heterogeneity, which might otherwise bias our estimates, and corrects for the endogeneity of all the regressors - not just trade. However, the effectiveness of this estimator critically depends on how well lagged values instrument for the endogenous 
variables in our regression. Thus, each estimation strategy should complement, rather than substitute for the other. Below, we describe the instruments used in the cross-sectional estimator and the GMM-estimation technique in greater detail.

\section{Correcting for Endogeneity in the Cross-Sectional Estimator}

The gravity model of trade was first applied to international trade by Tinbergen (1962). ${ }^{6}$ In its simplest form it posits that the volume of bilateral trade between two countries is a direct function of the output in each country and an inverse function of the distance between them. Formally, $T_{n k j}=\frac{Y_{n j}^{\beta_{n}} Y_{k j}^{\beta_{k}}}{D_{n k}^{\gamma}}$, where $T_{n k j}$ is the bilateral trade volume between countries $n$ and $k$ for a given industry $j, Y_{n j}$ and $Y_{k j}$ are the value-added of industry $j$ in countries $n$ and $k$, and $D_{n k}$ is the distance separating the two countries. By taking logs it becomes: $\ln \left(T_{n k j}\right)=\beta_{n} \ln Y_{n j}+\beta_{k} \ln Y_{k j}-\gamma \ln D_{n k}$. It is also standard to incorporate various dummies that capture, for instance, the effects of common borders, etc.

We follow Frankel and Romer (1999) and estimate the following variant of gravity model of trade, which takes into account only the exogenous component of trade:

$$
\ln \left(\frac{T_{n k j}}{Y_{n j}}\right)=-\gamma \ln D_{n k}+\beta_{1} N_{n}+\beta_{2} N_{k}+\beta_{3} A_{n}+\beta_{4} A_{k}+\beta_{5} B_{n k}+v_{n k},
$$

where $N_{n}$ and $N_{k}$ control for the population in countries $n$ and $k$ respectively; $A_{n}$ and $A_{k}$ are the areas of the two countries; $B_{n k}$ is a dummy variable which takes the value of one, in case countries share a common border and $v_{n k}$ is the error term.

Physical distance and country adjacency are proxies for transportation costs. By knowing how far a country is located and whether other countries surround it, provides 
considerable information about the amount it trades. Therefore, we expect a negative relation between bilateral trade volumes and distance, as well as, absence of common border.

The size of the country is also an important factor in explaining bilateral trade flows. Assuming that resources are equally distributed across countries, larger in terms of land countries are expected to engage less in trade with other countries than smaller countries. The same holds for large countries in terms of population. Residents of large populated countries tend to trade more with their fellow citizens simply because there are more people to trade with. Consequently, large countries (both in population and size) tend to be more selfsufficient, exploit economies of scale and involve less in trade. Therefore, the estimated coefficients on population and area (size) could well be negative or positive, depending on the relative characteristics of the countries involved in trade.

An important consideration arises within the current context. Since our data is observed at the industry-level, the measure of distance used to estimate the bilateral trade volume for some industry is the same for each of the industries within any two given countries. It is important, therefore, to allow the coefficient estimates to vary by industry. These differences in coefficient estimates can capture industry-specific factors related to average trade volumes and transportation costs. Aside from these differences, the exogenous component of trade captured in these regressions, is the same across industries. Moreover, it is the same whether we focus on imports, exports, or the total volume of trade. This approach therefore is not perfect and without drawbacks and it is important to keep these caveats in mind when interpreting our results.

The fitted values from equation (7) can be used to obtain an instrument for aggregate trade volume (imports, exports) for any given industry in a country. This is obtained by 
summing the fitted values for the bilateral trade volumes across countries. ${ }^{7}$ Table 1 below reports the correlation coefficients between actual and fitted bilateral trading volumes.

\section{(INSERT Table 1 Here)}

The gravity model of trade we estimate fits the data quite well for each industry. The $R^{2}$ varies between 0.62 and 0.85 , and the correlation between actual bilateral trading volumes and fitted values varies between a low of 0.79 and a high of 0.92 . Not surprisingly, a similarly good fit is obtained when we focus only on bilateral import or bilateral export volumes.

\section{Correcting for Endogeneity in the Panel Estimator}

While the cross-sectional estimator helps us determine to what extent the cross-sectional variation in productivity growth can be attributed to the exogenous component of trading volumes, it has a number of drawbacks. First, the estimator does not utilize the time-series dimension of the data, and thus it does not provide an answer to whether greater volumes of trade within an industry over time have had an effect on productivity growth of that industry. Second, the cross-sectional estimator does not correct for simultaneity biases arising on account of the inclusion of other endogenous controls. Third, the omission of important controls could potentially bias the coefficient estimates. Fourth, in industry-level data is difficult to distinguish the impact of imports versus exports, since the same measures of distance, size, and population are utilized to pull out the exogenous component in each case.

Thus, to overcome such problems and check the sensitivity of our findings, we employ the panel estimator proposed by Arellano and Bond (1991) to estimate equation (6) using data averaged over five-year windows. In this estimator country-specific effects are removed by first-differencing the data. Arellano and Bond (1991) then propose using an 
increasing sequence of lagged values of the endogenous and predetermined variables to correct for potential biases. Specifically, the endogenous variables lagged twice (or more) are valid instruments for their first differences.

\section{Data}

Our sample consists of twelve countries (Canada, Denmark, Finland, France, Germany, Italy, Japan, Netherlands, Norway, Sweden, UK, and USA) and nine two-digit industries (ISIC 3139) over the period 1978-1997, where the maximum number of industries, countries, and variables for our analysis is available. The industries considered in the analysis and their ISIC codes are presented in Table 2 below. Annual raw data are derived from various sources. The same International Standard Industries Classification (ISIC) code was used in all industry data sources. See Appendix for details on data and sources.

\section{(INSERT Table 2 Here)}

Mean rates of TFP growth by country and industry are reported in Table A.1 in Appendix. Briefly, we could say that there is some heterogeneity in the rates of TFP growth across countries and industries. On average, in almost all industries, the identity of the frontier country remains constant (see Table A.2 in the Appendix). However, it is not the identity of the frontier per se that matters in the econometric specification, but rather the measure of relative distance between each industry and the technological frontier, which captures the potential for technology transfer. 


\section{Results}

\section{Cross-Sectional Results}

We begin by presenting the results from our benchmark cross-sectional model. The average total factor productivity growth in each industry is regressed against the average total factor productivity growth in the frontier country for that industry, the technological gap, imports, exports, total trade share and a variable which controls for the size of the industry. ${ }^{8}$

\section{(INSERT Table 3 Here)}

The results from the standard least squares estimator, presented in columns (1) to (4) in Table 3, provide quite strong evidence of convergence in productivity across our sample since the coefficient on the gap variable is negative and statistically significant in all cases. Moreover, there is evidence that technology spills over from the frontier. These findings are quite consistent with earlier studies (Griffith et al., 2004). In addition, a positive and significant coefficient on the size variable suggests possible scale effects.

While no attempts have been made to control for simultaneity at this point, the coefficient on the trade variables are quite informative. First, the marginal influence of trade appears to be quite small. Second, the impact of an increase in exports share is roughly equivalent to the impact of an increase in imports share. Since the cross-sectional correlation between these two variables is quite high (0.66), this finding does not come as a surprise. However, the inability to differentiate across these two variables could reflect omitted variables bias.

In column (5) we address this concern by including a number of other controls that have been found to have an important influence on industry's productivity performance. 
Specifically, we add research and development expenditures share of value-added, price-cost margin, government expenditures share of GDP and sunk costs.

Introducing these additional controls has virtually no effect on the size of the coefficients on the trade variables. The total trade volume does appear to be statistically insignificant. The coefficients on the rest of the control variables are consistent with earlier studies (Garcia Pascual and Cheung, 2004) and easily interpreted, however, in most of the cases, are statistically insignificant. The only exception is the estimated coefficient on pricecost margin variable which is negative and statistically significant suggesting that increased competition has a positive effect on productivity growth.

In Table 4, we repeat the same analysis as in Table 3, using instrumental-variables (IV) estimator based on the gravity model of trade (equation 7). Columns (1) to (3) and (6) correspond to columns (2) to (5) of Table 3.

\section{(INSERT Table 4 Here)}

The findings of columns (1) to (3) point to a strong and statistically significant relationship between trade and productivity growth. As to the rest of the variables, it seems that there is no significant change between the estimates of the two tables, 3 and 4 . Along these lines, we conclude that once we instrument for trade, its estimated impact on industry's productivity growth becomes quantitatively large and statistically significant $-\mathrm{a}$ finding in line with the study of Frankel and Romer (1999).

Compared to the OLS, the IV estimates are not only statistically significant but also quantitatively larger - almost doubled. Prevailing views, however, suggest that the IV estimates of trade's impact on productivity growth would be smaller in size than those of the OLS. ${ }^{9}$ A possible explanation for our finding is that the OLS estimates are actually biased 
down, therefore, they tend to underestimate the true effect of all growth-enhancing interactions i.e., exchange of ideas, specialization, spillover effects, and so on that take place in trading goods (Frankel and Romer 1999).

\section{Panel Results}

In order to explore the time series variation in the data and address some of the shortcomings of the cross-sectional estimator, we re-estimate our productivity growth equation using panel data. In doing so, we employ the first-difference one-step GMM-estimator developed by Arellano and Bond (1991). The results are reported in Table 5.

\section{(INSERT Table 5 Here)}

The results from columns (1) to (3), which correspond to the first specifications of the cross-sectional analysis, reveal again a positive effect of trade on productivity growth ${ }^{10}$. However, they also suggest that an increase in outward orientation and increased exporting has little or no influence on productivity growth. Instead, industries seem to benefit from increased imports. The inclusion of additional controls (columns 4-6) does not alter these results. Imports continue to play a significant role on productivity growth, whereas the coefficient of exports continues to be statistically insignificant.

Some of the results with respect to rest of the variables also differ in the panel specification. Note for instance, the coefficient on technological gap has no longer in all specifications a statistically significant impact on productivity growth. In part, this may reflect more limited variation in productivity differentials over time as opposed to across industries.

Another notable difference between the cross-sectional and panel data results is the variable, sunk costs, continues to be not only negative, as it was in our earlier findings, but 
also statistically significant in each of the specifications in columns (4) to (6). As to research and development and government spending share, these variables continue to have a positive impact on productivity growth, however, the effect is statistically insignificant.

Arellano and Bond (1991) suggest two tests to assess the validity of the model. Crucially, second-order serial correlation should be absent; and the results meet that test. They also suggest a Sargan test for over-identifying restrictions. In the basic specification, the null hypothesis that over-identifying restrictions are valid cannot be rejected, but this is not the case in the more general specification. While this is of some concern, it is well-known that in finite samples the Sargan test statistics obtained from the one-step Arellano-Bond estimator often over-reject the null in the presence of heteroscedasticity (Arellano and Bond, 1991). ${ }^{11}$

Sensitivity analysis suggested qualitatively similar findings when using alternative conditioning information sets, data at various frequencies and various sub-samples. ${ }^{12}$ Summing up, increased exposure to trade is found to have a positive and statistically significant effect on productivity growth in the cross-sectional data (IV estimator). This is true for both imports and exports. However, the inclusion of additional controls weakens the impact of exports. Within the panel data, only a robust link between import share and productivity growth is present. The effect of exports is limited. Comparing our findings to the past related literature, we could say they are in line with the study of Griffith et al. (2004), which also points to the direction of a positive but quantitative small effect of trade on industries' productivity growth. 


\section{Conclusion}

The paper investigates the impact of trade on TFP growth in the manufacturing sector across twelve OECD countries over the period 1978-1997. Overall, our results indicate that trade has a positive effect on productivity growth. However this effect is rather small. There is also some indication that imports are more important for productivity growth than exports. Industries benefit from increased imports perhaps because greater exposure to higher quality foreign goods lowers the costs of imitation of foreign advanced technologies or places greater pressure on domestic industries to adopt new technologies and improve efficiency. This finding comes across particularly strong in our panel estimators, where there the impact of exports on productivity growth is negligible.

\section{References}

Aghion, Philippe; Harris, Christopher and John Vickers, "Competition and Growth with Step-by-Step Innovation: An Example,” European Economic Review 41 (1997):771-82.

Aghion, Philippe and Peter Howitt, Endogenous Growth Theory, Cambridge, MA: MIT Press, 1998.

Arellano, Manuel and Stephen Bond, "Some Tests of Specification for Panel Data: Monte Carlo Evidence and an Application to Employment Equations," Review of Economic Studies 58 (1991):277-97.

Aschauer, David A., "Is Public Expenditure Productive?," Journal of Monetary Economics 23 (1989):177-200.

Barro, Robert, "Government Spending in a Simple Model of Endogenous Growth," Journal of Political Economy 98 (1990):103-17. 
Barro, Robert and Xavier Sala-i-Martin, Economic Growth, Boston, MA: McGraw Hill Inc., 1995.

Ben-David, Dan and Michael B. Loewy, "Free Trade, Growth, and Convergence," Journal of Economic Growth 3 (1998):143-70.

Bergstrand, Jeffrey H., "The Gravity Equation in International Trade: Some Micro-Economic Foundations and Empirical Evidence," Review of Economics and Statistics 67 (1985):474-81.

Bernard, Andrew B., and Charles I. Jones, "Comparing Apples to Oranges: Productivity Convergence and Measurement across Industries and Countries," American Economic Review 86 (1996):1216-38.

Bhagwati, Jagdish N., "The Capital Myth: The Difference between Trade in Widgets and Dollars," Foreign Affairs Issue 77 (1998):7-12.

Cameron, Gavin; Proudman, James and Stephen Redding, "Technological Convergence, R\&D, Trade and Productivity Growth," European Economic Review 49 (2005):775-807.

Campa, Jose and Linda S. Goldberg, "Investment in Manufacturing, Exchange Rates and External Exposure,” Journal of International Economics 38 (1995):297-320.

Caves, Douglas W.; Christensen, Laurits R. and Erwin W. Diewert, "The Economic Theory of Index Numbers and the Measurement of Input, Output and Productivity," Econometrica 50 (1982):1393-414.

Cheung, Yin-Wong; Chinn, Menzie and Eiji Fujii, "Market Structure and the Persistence of Sectoral Real Exchange Rates," International Journal of Finance and Economics 6 (2001):95-114. 
Cheung, Yin-Wong and Antonio-Garcia Pascual, "Market Structure, Technology Spillovers, and Persistence in Productivity Differentials," International Journal of Applied Economics 1 (2004):1-23.

Connolly, Michelle, “The Dual Nature of Trade: Measuring its Impact on Imitation and Growth,” Duke University, Working Paper No. 97-34, 1998.

Deardorff, Alan V., "Determinants of Bilateral Trade: Does Gravity Work in a Neoclassical World?," in J. Frankel (ed.), The Regionalization of the World Economy, Chicago: University of Chicago Press, 1998.

Dixit, Avinash K., "Entry and Exit under Uncertainty," Journal of Political Economy 97 (1989):620-38.

Domowitz, Ian; Glenn, Hubbard and Bruce C. Petersen, "Business Cycles and the Relationship between Concentration and Price-Cost Margins," Rand Journal of Economics 17 (1986):1-17.

Edwards, Sebastian, "Openness, Productivity and Growth: What do We Really Know," Economic Journal 108 (1998):383-98.

Feenstra, Robert; Markusen, James and Andrew Rose, "Using the Gravity Equation to Differentiate among Alternative Theories of Trade," Canadian Journal of Economics 34 (2001):430-47.

Frankel, Jeffrey, Regional Trading Blocs in the World Trading System, Washington D.C.: Institute of International Economics, 1997.

Frankel, Jeffrey and David Romer, "Does Trade Cause Growth?," American Economic Review 89 (1999):379-99. 
Frankel, Jeffrrey and Andrew Rose, "An Estimate of the Effects of Currency Unions on Trade and Growth,” Quarterly Journal of Economics 117 (2002):437-66.

Griffith, Rachel; Redding, Stephen and John van Reenen, "Mapping the Two Faces of R\&D: Productivity Growth in a Panel of OECD Industries," Review of Economics and Statistics 86 (2004):883-95.

Grossman, Gene M. and Elhanan Helpman, Innovation and Growth in the Global Economy, Cambridge, MA: MIT Press, 1991.

Harrison, Ann, "Openness and Growth: A Time-Series, Cross-Section Analysis for Developing Countries," Journal of Development Economics 48 (1996):419-47.

Helpman, Elhanan, "Multinational Corporations and Trade Structure," Review of Economic Studies 52 (1984):443-57.

Keller, Wolfgang, “Are International R\&D Spillovers Trade-related? Analyzing Spillovers among Randomly Matched Trade Partners,” European Economic Review 42 (1999):1469-81. Kneller, Richard; Bleaney, Michael F. and Norman Gemmell, "Fiscal Policy and Growth: Evidence from OECD Countries," Journal of Public Economics 74 (1999):171-90.

Levine, Ross and David Renelt, "A Sensitivity Analysis of Cross-Country Growth Regressions," American Economic Review 82 (1992):942-63.

Lucas, Robert, "Supply-Side Economics: An Analytical Review," Oxford Economic Papers 42 (1990):293-316.

MacDonald, James M., "Does Import Competition Force Efficient Production?," Review of Economics and Statistics 76 (1994):721-27.

Rivera-Batiz, Luis and Paul Romer, "Economic Integration and Endogenous Growth," Quarterly Journal of Economics 106 (1991):531-55. 
Rodriguez, Francisco and Dani Rodrik, “Trade Policy and Economic Growth: A Skeptic's Guide to Cross-National Evidence," National Bureau of Economic Research, Working Paper No. 7081, 1999.

Romer, Paul, "Increasing Returns and Long-Run Growth," Journal of Political Economy 94 (1986):1002-37.

, "Endogenous Technological Change," The Journal of Political Economy 98 (1990):71-102.

Scarpetta, Stefano and Thierry Tressel, "Productivity and Convergence in a Panel of OECD Industries: Do Regulations and Institutions Matter?," Organization for Economic Cooperation and Development, Working Paper No. 342, 2002.

Tinbergen, Jan, Shaping the World Economy: Suggestions for an International Trade Policy, New York: The Twentieth Century Fund, 1962. 


\section{Notes}

1. Geography provides considerable information about the amount that countries trade, and since there is no likely channel through which it can affect productivity growth other than through trade, serves as a good instrument for trade.

2. See Ben-David and Loewy (1998), Connolly (1998), Frankel and Romer (1999) and Cameron et al. (2005) among others.

3. Endogenous growth models suggest that there is both a temporary effect from government intervention during transition to equilibrium, and a possible long-term effect from government spending on economic growth (Romer, 1986; Lucas, 1990). Several works (Barro, 1990; Barro and Sala-i-Martin, 1995; Kneller et al., 1999) provide evidence on the role of government actions in affecting growth via public provision of infrastructure such as roads, airports, harbors, public sector R\&D and investment in human capital.

4. See Barro and Sala-i-Martin (1995) and Kneller et al. (1999) for a discussion.

5. In the cross-sectional specification, the time subscript is suppressed while in the panel data the constant term is replaced with a country-industry-specific intercept. In both specifications, variables are expressed in natural logarithms. Trade $(T)$ and control variables $(X)$ are in ratios.

6. For theoretical justification of the gravity model of trade, see Helpman (1984), Bergstrand (1985) and Deardorff (1998). For empirical applications, see Feenstra et al. (2001) and Frankel and Rose (2002) among others.

7. The estimated coefficients of our gravity equation are in line with those of Frankel and Romer (1999, p. 384) and Frankel (1997, p. 70-72). We find that 1\% increase in distance, reduces trade flows from $0.7 \%$ to $1.1 \%$ (varies with industry); the impact of $1 \%$ increase in 
country's population on trade flows ranges from $-0.24 \%$ to $0.80 \%$ while the impact of $1 \%$ increase in country's area reduces trade flows from $0.11 \%$ to $0.20 \%$. Finally, lack of adjacency with trading partners reduces trade flows from $0.3 \%$ to $0.4 \%$. Results are robust at $5 \%$ level and available upon request.

8. Size - proxied by the value-added of the industry at the beginning of the sample period - is used to control for scale effects.

9. Due to omitted variable bias, a positive correlation between trade and error term in the OLS regression leads to an upward bias in the OLS estimates of trade share. Since there is no reason to expect correlation between geographical characteristics and various omitted country-industry characteristics, there is no reason to expect the IV estimates would suffer from the same bias.

10. SIZE and $P C M$ drop out from the panel data estimation since they do not vary considerably over the period under investigation.

11. While standard errors robust to heteroscedasticity can be obtained, the distribution of the Sargan test is unknown in this case. Thus, the Sargan test statistic reported for the one-step estimator should be treated with caution. For this reason, researchers sometimes rely on the Sargan test statistics from the two-step estimator, which in this case does not lead to a rejection of the null hypothesis that the over-identifying restrictions are in fact valid. 12. Results are available upon request. 


\section{Appendix}

\section{Data and Sources:}

Value-added (VA): gross value-added expressed in 1990 constant prices (BN \$ US). Data on value-added are retrieved from the OECD International Sectoral Database (ISDB), 1998.

Capital stock (K): gross capital stock, measured in 1990 constant prices (BN \$ US). Data on capital stock are retrieved from the OECD International Sectoral Database (ISDB), 1998.

Labor $(L)$ : annual hours worked in an industry, expressed in thousands. Data on labor come from the OECD International Sectoral Database (ISDB), 1998.

Trade (T): trade share (Trade), exports share (Export), imports share (Import) expressed as ratio of trade (exports + imports) flows, export flows and import flows to value-added. Data on bilateral trade flows are obtained from the United Nations Industrial Development Organization (UNIDO) Bilateral Trade Flows, 2002.

Research and Development $(R \& D)$ : $\mathrm{R} \& \mathrm{D}$ expenditures as a share of value-added. Data on R\&D flows come from the OECD Business Enterprise Expenditure on Research and Development (BERD), 2002.

Price-Cost Margin (PCM): constructed as, $P C M=\frac{V A-L C}{V}$, where $V A$ is value-added, $L C$ is labor cost and $V$ production (sales). Data on labor cost are retrieved from the OECD International Sectoral Database (ISDB), 1998, while data on production from the OECD Structural Analysis Database (STAN), 2002.

Sunk Costs (Sunk): constructed as, Sunk $=\frac{I}{V}$, where $I$ is physical investment and $V$ production. Data on physical investment come from the OECD Structural Analysis Database (STAN), 2002. 
Government Spending (Government): expressed as ratio of spending (on education, infrastructure, transportation) to GDP. Data on government spending were obtained from the International Monetary Fund (IMF) Government Financial Statistics, 2001.

Area (A), Population (N), Border (B): expressed in squared miles, millions, and 0 (no common border) and 1 (for common border), respectively. Data are retrieved from the Central Intelligence Agency (CIA) World Factbook, 2004.

Tables:

Table A.1. Mean Annual Growth Rate of TFP, 1978-1997 (\%).

\begin{tabular}{cccccccccc|ccc}
\hline \hline & $\mathbf{3 1}$ & $\mathbf{3 2}$ & $\mathbf{3 3}$ & $\mathbf{3 4}$ & $\mathbf{3 5}$ & $\mathbf{3 6}$ & $\mathbf{3 7}$ & $\mathbf{3 8}$ & $\mathbf{3 9}$ & MEAN & MIN & MAX \\
\hline $\boldsymbol{C A N}$ & 0.202 & 0.249 & 0.404 & 0.317 & -0.255 & -0.176 & 0.049 & -0.051 & 0.406 & 0.212 & -0.255 & 1.176 \\
$\boldsymbol{D N K}$ & -1.109 & -1.171 & -0.902 & -0.924 & -1.237 & -1.172 & -2.510 & -1.164 & -1.108 & -1.289 & -2.510 & -0.715 \\
$\boldsymbol{F I N}$ & -1.432 & -1.307 & -1.015 & -0.919 & -1.509 & -1.324 & -1.478 & -1.336 & -1.011 & -1.422 & -2.886 & -0.919 \\
$\boldsymbol{F R} \boldsymbol{A}$ & 0.606 & 0.908 & 0.428 & 0.646 & 0.844 & 0.631 & 0.544 & 0.670 & 0.321 & 0.615 & 0.270 & 0.908 \\
$\boldsymbol{G E R}$ & 0.896 & 0.864 & 1.091 & 0.595 & 1.299 & 1.013 & 1.369 & 1.119 & 0.311 & 0.979 & 0.311 & 1.369 \\
$\boldsymbol{I T \boldsymbol { A }}$ & 0.432 & 1.402 & 0.880 & -0.044 & 0.359 & 0.922 & 0.439 & 0.429 & -0.743 & 0.419 & -0.743 & 1.402 \\
$\boldsymbol{J A P}$ & 1.271 & 0.552 & 0.068 & 0.062 & 1.100 & 1.054 & 1.485 & 1.048 & 2.721 & 1.084 & 0.062 & 2.721 \\
$\boldsymbol{N L \boldsymbol { D }}$ & -0.507 & -0.840 & -0.749 & -0.325 & -0.236 & -0.725 & -0.889 & -0.526 & -0.806 & -0.654 & -1.050 & -0.236 \\
$\boldsymbol{N O R}$ & -1.350 & -2.063 & -1.434 & -1.035 & -1.534 & -1.256 & -1.283 & -1.438 & -1.012 & -1.314 & -2.063 & -1.003 \\
$\boldsymbol{S W E}$ & -0.762 & -1.102 & -0.181 & -0.372 & -0.671 & -0.901 & -0.795 & -0.512 & -1.765 & -0.634 & -1.765 & 0.004 \\
$\boldsymbol{U K}$ & 0.555 & 0.819 & 0.054 & 0.823 & 0.731 & 0.765 & 1.232 & 0.428 & 0.292 & 0.601 & 0.054 & 1.232 \\
$\boldsymbol{U S \boldsymbol { A }}$ & 1.493 & 1.719 & 1.879 & 1.875 & 1.632 & 1.270 & 1.654 & 1.622 & 1.701 & 1.612 & 1.270 & 1.879 \\
\hline
\end{tabular}

31: Food, Beverages and Tobacco; 32: Textiles; 33: Wood; 34: Paper; 35: Chemicals; 36: Non-Metallic Minerals; 37: Basic Metals; 38: Fabricated Metals; 39: Other Manufacturing.

Table A.2. Leading Countries per Industry, 1978-1997 (TFP growth).

\begin{tabular}{cccccccccc}
\hline & $\mathbf{3 1}$ & $\mathbf{3 2}$ & $\mathbf{3 3}$ & $\mathbf{3 4}$ & $\mathbf{3 5}$ & $\mathbf{3 6}$ & $\mathbf{3 7}$ & $\mathbf{3 8}$ & $\mathbf{3 9}$ \\
\hline \multirow{2}{*}{ First } & USA & USA & USA & USA & USA & USA & USA & USA & JAP \\
Second & JAP & ITA & GER & UK & GER & JAP & JAP & GER & USA
\end{tabular}

31: Food, Beverages and Tobacco; 32: Textiles; 33: Wood; 34: Paper; 35: Chemicals; 36: Non-Metallic Minerals; 37: Basic Metals; 38: Fabricated Metals; 39: Other Manufacturing. 
Table 1. Gravity Model of Trade: Assessing the Goodness of Fit.

\begin{tabular}{|c|c|c|c|c|c|c|}
\hline $\begin{array}{l}\text { ISIC } \\
\text { Code }\end{array}$ & \multicolumn{2}{|c|}{$\begin{array}{l}\text { Trade (imports }+ \text { exports) } \\
\text { volumes }\end{array}$} & \multicolumn{2}{|c|}{ Import volumes } & \multicolumn{2}{|c|}{ Export volumes } \\
\hline & $\begin{array}{c}\text { Correlation } \\
\text { with actual } \\
\text { values } \\
\end{array}$ & $\mathrm{R}^{2}$ & $\begin{array}{c}\text { Correlation } \\
\text { with actual } \\
\text { values } \\
\end{array}$ & $\mathrm{R}^{2}$ & $\begin{array}{c}\text { Correlation } \\
\text { with actual } \\
\text { values } \\
\end{array}$ & $\mathrm{R}^{2}$ \\
\hline 31 & 0.85 & 0.72 & 0.80 & 0.63 & 0.86 & 0.73 \\
\hline 32 & 0.91 & 0.83 & 0.88 & 0.77 & 0.92 & 0.85 \\
\hline 33 & 0.80 & 0.64 & 0.76 & 0.58 & 0.91 & 0.83 \\
\hline 34 & 0.79 & 0.62 & 0.81 & 0.66 & 0.90 & 0.79 \\
\hline 35 & 0.92 & 0.85 & 0.94 & 0.88 & 0.92 & 0.85 \\
\hline 36 & 0.89 & 0.80 & 0.90 & 0.81 & 0.91 & 0.82 \\
\hline 37 & 0.90 & 0.80 & 0.86 & 0.80 & 0.92 & 0.84 \\
\hline 38 & 0.90 & 0.82 & 0.93 & 0.86 & 0.91 & 0.84 \\
\hline 39 & 0.84 & 0.72 & 0.87 & 0.75 & 0.84 & 0.71 \\
\hline
\end{tabular}


Table 2. Manufacturing Industries and ISIC Codes.

\begin{tabular}{cl}
\hline ISIC (rev. 2) Code & Manufacturing Industries \\
\hline 31 & Food, Beverages and Tobacco \\
32 & Textiles, Apparel and Leather \\
33 & Wood Products and Furniture \\
34 & Paper, Printing and Publishing \\
35 & Chemical Products \\
36 & Non Metallic Mineral Products \\
37 & Basic Metal Industries \\
38 & Fabricated Metal Products \\
39 & Other Manufacturing \\
\hline
\end{tabular}


Table 3. Cross-Sectional Regressions, OLS Estimator.

\begin{tabular}{|c|c|c|c|c|c|}
\hline $\begin{array}{l}\text { Dependent variable: } \\
\text { TFP growth }\end{array}$ & (1) & (2) & (3) & (4) & (5) \\
\hline Frontier TFP growth & $\begin{array}{l}0.4113 \\
(4.03)\end{array}$ & $\begin{array}{l}0.3820 \\
(3.69)\end{array}$ & $\begin{array}{l}0.3832 \\
(3.70)\end{array}$ & $\begin{array}{l}0.3851 \\
(3.76)\end{array}$ & $\begin{array}{l}0.2783 \\
(2.80)\end{array}$ \\
\hline Gap & $\begin{array}{l}-0.0172 \\
-(5.85)\end{array}$ & $\begin{array}{l}-0.0200 \\
-(5.35)\end{array}$ & $\begin{array}{c}-0.0176 \\
(4.57)\end{array}$ & $\begin{array}{l}-0.0185 \\
-(4.96)\end{array}$ & $\begin{array}{l}-0.0195 \\
-(4.58)\end{array}$ \\
\hline Size & & $\begin{array}{l}0.0027 \\
(1.92)\end{array}$ & $\begin{array}{c}0.0021 \\
(1.71)\end{array}$ & $\begin{array}{c}0.0027 \\
(2.00)\end{array}$ & $\begin{array}{c}0.0065 \\
(2.67)\end{array}$ \\
\hline Import & & $\begin{array}{c}0.0034 \\
(1.86)\end{array}$ & & & \\
\hline Export & & & $\begin{array}{r}0.0031 \\
(1.80)\end{array}$ & & \\
\hline Trade & & & & $\begin{array}{c}0.0036 \\
(2.04)\end{array}$ & $\begin{array}{c}0.0028 \\
(1.66)\end{array}$ \\
\hline$R \& D$ & & & & & $\begin{array}{l}0.0287 \\
(0.68)\end{array}$ \\
\hline$P C M$ & & & & & $\begin{array}{l}-0.0103 \\
-(4.96)\end{array}$ \\
\hline Government & & & & & $\begin{array}{l}0.0042 \\
(1.64)\end{array}$ \\
\hline Sunk & & & & & $\begin{array}{l}-0.0014 \\
-(0.75)\end{array}$ \\
\hline$R$ squared & 0.37 & 0.40 & 0.40 & 0.40 & 0.58 \\
\hline \#obs. & 90 & 90 & 90 & 90 & 87 \\
\hline
\end{tabular}


Table 4. Cross-Sectional Regressions, IV Estimator.

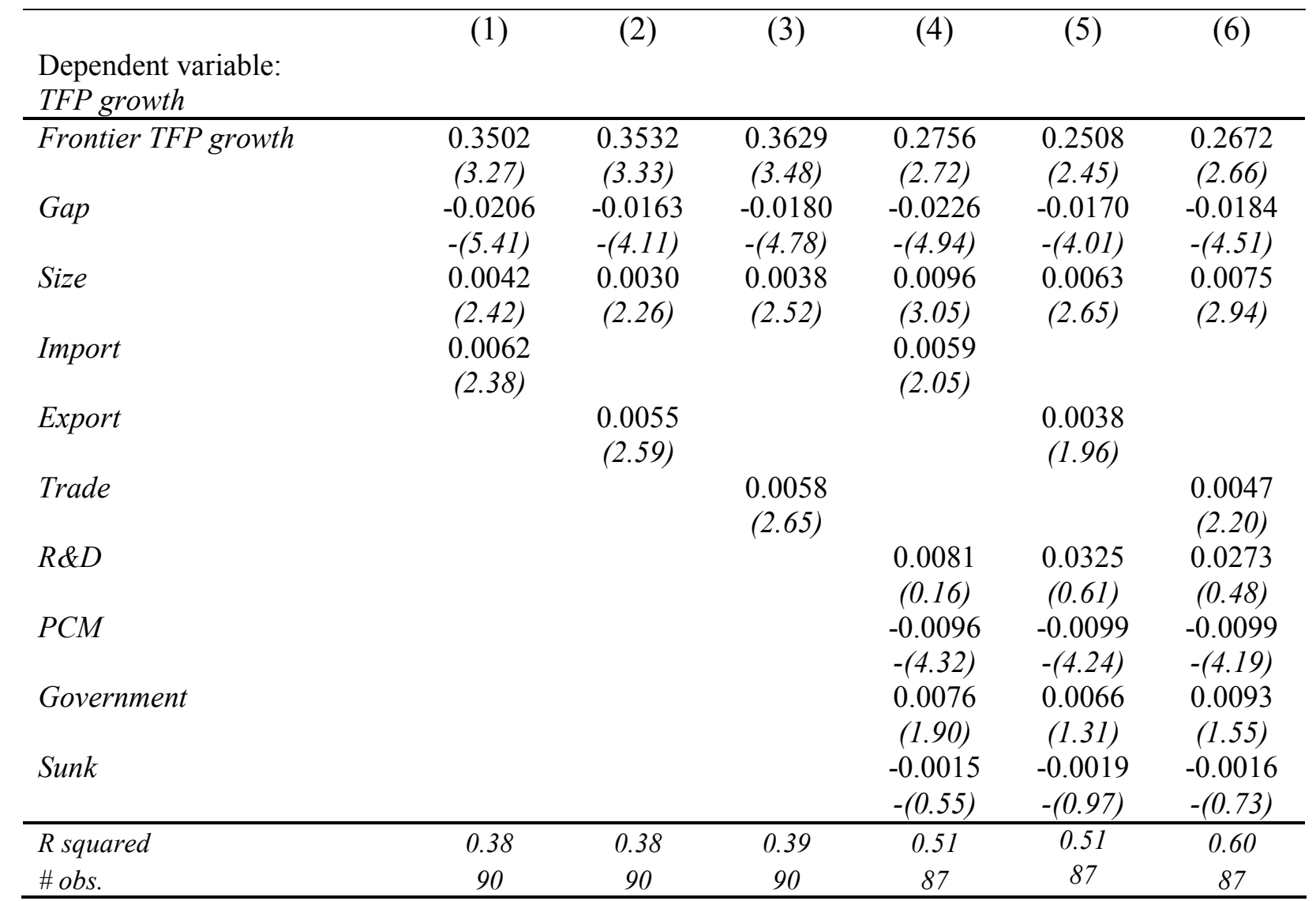


Table 5. Panel Regressions, GMM Estimator

\begin{tabular}{|c|c|c|c|c|c|c|}
\hline $\begin{array}{l}\text { Dependent variable: } \\
\text { TFP growth }\end{array}$ & (1) & (2) & (3) & (4) & (5) & (6) \\
\hline Frontier TFP growth & $\begin{array}{l}0.2548 \\
(1.66)\end{array}$ & $\begin{array}{c}0.2094 \\
(1.30)\end{array}$ & $\begin{array}{l}0.2226 \\
(1.39)\end{array}$ & $\begin{array}{l}0.4133 \\
(3.72)\end{array}$ & $\begin{array}{l}0.3825 \\
(3.51)\end{array}$ & $\begin{array}{c}0.3974 \\
(3.47)\end{array}$ \\
\hline Gap & $\begin{array}{r}0.0130 \\
(0.99)\end{array}$ & $\begin{array}{r}0.0043 \\
(0.30)\end{array}$ & $\begin{array}{r}0.0099 \\
(0.75)\end{array}$ & $\begin{array}{l}0.0191 \\
(1.36)\end{array}$ & $\begin{array}{c}0.0036 \\
(0.17)\end{array}$ & $\begin{array}{r}0.0166 \\
(0.77)\end{array}$ \\
\hline Import & $\begin{array}{l}0.0098 \\
(1.99)\end{array}$ & & & $\begin{array}{l}0.0106 \\
(2.13)\end{array}$ & & \\
\hline Export & & $\begin{array}{r}0.0047 \\
(0.46)\end{array}$ & & & $\begin{array}{c}0.0020 \\
(0.47)\end{array}$ & \\
\hline Trade & & & $\begin{array}{c}0.0055 \\
(1.50)\end{array}$ & & & $\begin{array}{c}0.0048 \\
(1.88)\end{array}$ \\
\hline$R \& D$ & & & & $\begin{array}{l}0.5290 \\
(0.49)\end{array}$ & $\begin{array}{l}0.4751 \\
(0.99)\end{array}$ & $\begin{array}{c}0.3664 \\
(0.21)\end{array}$ \\
\hline Government & & & & $\begin{array}{c}0.0403 \\
(0.97)\end{array}$ & $\begin{array}{c}0.0754 \\
(1.58)\end{array}$ & $\begin{array}{r}0.0593 \\
(1.17)\end{array}$ \\
\hline Sunk & & & & $\begin{array}{l}-0.0320 \\
-(1.86)\end{array}$ & $\begin{array}{l}-0.0465 \\
-(2.11)\end{array}$ & $\begin{array}{l}-0.0375 \\
-(2.01)\end{array}$ \\
\hline $1^{\text {st }}$ order serial correlation $p$-value & 0.00 & 0.00 & 0.00 & 0.00 & 0.00 & 0.00 \\
\hline $2^{\text {nd }}$ order serial correlation $p$-value & 0.59 & 0.41 & 0.52 & 0.76 & 0.99 & 0.88 \\
\hline Sargan $J$ (p-value) & 0.64 & 0.85 & 0.74 & 0.09 & 0.08 & 0.07 \\
\hline
\end{tabular}

